\title{
Кллінічний випадок складності діагностики та хірургічного лікування позакишкових ускладнень при неспецифічному виразковому коліті, асоційованому з цукровим діабетом типу 2
}

У статті наведено випадок складності діагностики та лікування позакишкового ускладнення неспецифічного виразкового коліту та супутнього цукрового діабету 2 типу у вигляді некротичних змін тканин верхніх та нижніх кінцівок.

Ключові слова: неспецифічний виразковий коліт; цукровий діабет 2 типу, флегмона; діагностика; лікування.

Кожен випадок лікування пацієнта для лікаря іноді стає унікальним, особливо коли ускладнення відомого захворювання зустрічається не так часто. В нашому випадку на розвиток шкірного ускладнення пусковим фактором вважаємо все ж неспецифічний виразковий коліт, оскільки цукровий діабет у хворого мав легкий перебіг, термін його перебігу надто короткий для розвитку вказаної клінічної ситуації, однак його асоціація безперечно повпливала на її перебіг.

Опис клінічного випадку. Хворий 3., 35 років, госпіталізований у ревматологічне відділення КНП ”ТУЛ” ТОР 04.03.20 р. у стані середньої тяжкості 3 діагнозом: реактивний артрит, активність III ступеня з ураженням кистей, колінних, гомілковостопних суглобів. ФНС II ступеня. Супутній: цукровий діабет, тип 2, легка форма компенсований. 3 анамнезу: захворів 20.02.20 р., коли з'явився біль у суглобах, підвищення температури тіла до $38.5^{\circ} \mathrm{C}$, пізніше приєдналися проноси з домішками слизу, прожилків крові, сухість у роті, загальна слабість. Хворому призначено консервативну терапію, яка бажаного результату не принесла. Також хворому було виконано комплекс діагностичних маніпуляцій, серед яких ультразвукове дослідження органів черевної порожнини (патологічних змін не виявлено), ендоскопічна гастро-дуоденоскопія (хронічний гастродуоденіт у фазі загострення). Гастроезофагальний рефлюкс, колоноскопія - виявлено ознаки неспецифічного виразкового коліту з переважним ураження поперечно-ободової, низхідної та сліпої кишки. Було виконано біопсію уражених ділянок слизової товстого кишечника, матеріал відправили на патогістологічне дослідження, яке в подальшому підтвердило даний діагноз. На цукровий діабет хвоpiє 2 роки. Травм не мав, за чистотою тіла доглядає регулярно. 3 06.03.20 хворого турбує біль та почервоніння ділянок шкіри на правій гомілці по зовнішній поверхні в її верхній третині та на лівій гомілці в середній третині по зовнішній поверхні. Також хворий почав помічати біль та припухлість у дистальних фалангах 2-го пальця правої та 1-го пальця лівої кистей. 07.03.20 р. хворого оглянув хірург-подолог, який на момент огляду хворого встановив діагноз: флегмона верхньої третини правої гомілки та середньої третини лівої гомілки. Гнійний артрит 2-го пальця правої руки та флегмона 1-го пальця лівої руки. Було рекомендовано для подальшого хірургічного лікування перевести хворого в хірургічне відділення № 1 КНП “ТУЛ” TОР. Загальний аналіз крові: гемоглобін - 72 г/л, еритроцити - 2,34×10²/л, лейкоцити - 18,2×10\%/л, лейко. формула: п-23, с- 57, л-17, м-3. Глюкоза крові коливалась в межах 5,8-7,9 ммоль/л. Глікований гемоглобін - 6,4 \%. Загальний аналіз сечі: кількість 80 мл, колір - світло-солом'яний, слабомутна, білок: 0,033 г/л, епітеліальні клітини - поодинокі, лейкоцити - 1-2 у п. 3., еритроцити - 2-3 у п. з., біохімічне дослідження крові: загальний білок 57,2 г/л; сечовина 7,5 ммоль/л, креатинін 0,115 моль/л, білірубін загальний - 17,4 мкмоль/л, альфа-амілаза - 58,4 ОД/л, АЛТ - 17,2 ммоль/л, ACT - 19,2 ммоль/л. ПТІ - 68 \%. Група крові АВ (IV), Rh (+) позитивний. Електроліти крові: калій (сировотка) - 4,49 ммоль/л, кальцій іонізований - 1,03 ммоль/л, натрій (сировотка) - 130 ммоль/л, хлор (сировотка) - 101,17 ммоль/л. Прокальцитонін - 1,8 нг/мл (норма - менше 0,1). Ревматоїдний фактор 16.2. С-реактивний протеїн (сировотка) 256,5 мг/л. ЕКГ: ритм синусовий, регулярний, метаболічні зміни міокарда. В умовах хірургічного стаціонару хворому проводили інфузійну, протизапальну, антибактеріальну терапію. В ургентному порядку проведено хірургічну обробку флегмон та некректомію уражених ділянок правої та лівої го- 
мілок та хірургічну обробку флегмон на пальцях рук. Також взято матеріал на визначення бактеріальної флори та антибіотикочутливість, при якому було виявлено збудник staphilococus haemolyticus та його чутливість до ванкоміцину, левофлоксацину, цефтріаксону. Враховуючи тяжкість стану, пацієнту проведено 2 сеанси гемотрансфузії, які включали переливання еритроцитарної маси та кріоплазми сумісної групи $\mathrm{AB}(\mathrm{IV}) \mathrm{Rh}(+)$. На фоні проведеної антибіотикотерапії стан хворого не покращувався. 08.03.20 р. при огляді пацієнта виявлено прогресування гнійно-некротичних змін уражених ділянок обох гомілок. Впродовж доби в місцях запальних змін шкіри з'явилися гнійні виділення та площа уражених ділянок шкіри на обидвох гомілках різко збільшилась втричі. На момент огляду ділянка ураження на правій гомілці мала розмір 18x9 см та лівій 10х7см з ураженнями шкіри та підшкірно клітковини у вигляді сот.

У зв'язку з наявністю даних ознак після проведення передопераційної підготовки виконано ургентне операційне втручання під загальним знеболенням - хірургічна обробка гнійно-некротичних ран правої та лівої гомілок із розкриттям гнійних запливів, некректомія в межах здорових тканин, ампутація 2-го пальця правої кисті з резекцією головки основної фаланги електромеханічним методом, запропонованим Футуймою Ю. М. та співавт. (патент на корисну модель № 109065), хірургічна обробка флегмони 1-го пальця лівої кисті [6].

Враховуючи появу гнійних ускладнень на фоні клінічних проявів неспецифічного виразкового коліту в асоціації з цукровим діабетом 2 типу після операції встановлено остаточний діагноз: неспецифічний виразковий коліт, тяжка форма, лівобічне ураження. Флегмони верхньої третини правої гомілки та середньої третини лівої гомілки. Гнійний артрит міжфалангових суглобів 2-го пальця правої кисті та флегмона 1-го пальця лівої кисті. Синдром системної запальної відповіді. Супутній: цукровий діабет, тип 2, легкий перебіг, компенсований.

Хворий після операції перебував у палаті хірургічного відділення, де проводились щоденні перев'язки з антисептиками та комплексне лікування в об'ємі: цефтріаксон 1 г х 2 р/д в/в, левофлоксацин - 100 мл х 2 р в/в, метронідазол 100 мл х 3 рази в/в, альбумін $20 \%$ 100,0 в/в, глюкоза $5 \%$ 400,0, інфезол 500,0 в/в, реосорбілакт 400,0в/в, фленокс 0,2 мл п/ш, інфулган 100 мг в/в. Рани щоденно двічі обробляли антисептичними розчинами поперемінно з бетадиновим милом та милом “Цитеал”. Кожна перев’язка завершувала- ся промиванням антисептичними розчинами декасаном чи хлоргексидином методом “пульсуючого струменя”, запропонованим Чонкою I. I. [2, 5]. Поверхня рани закривалася серветками, змоченими в препарат українського виробництва фірми Дарниця “Діоксизоль”. Окрім того, проходив лікування неспецифічного виразкового коліту згідно зі загальносвітовими стандартами [1, 3, 7-10]. Впродовж 10 днів у післяопераційному періоді пацієнту виконували сеанси баротерапії. На фоні проведеного лікування стан хворого в динаміці покращувався. Післяопераційні рани гомілок гоїлись вторинним натягом, повторний бакпосів із рани - патогенної флори не виявлено що дало можливість на 9-ту добу післяопераційного періоду (рис. 1) на рани гомілок накласти вторинні шви $[4,11]$.

Враховучи велику ранову поверхню на правій гомілці, а також те, що на 15 добу (рис. 2) при повторному посіві з рани ми не виявили патогенних мікроорганізмів для пришвидшення поцесу загоєння вирішено виконати автодермопластику (рис. 3) з донорської ділянки правого стегна, яку було виконано 23.03.20 р. Під час операції в тій ділянці, де була оголена великогомілкова кістка, проведено остеоперфорацію сверлом 3 мм, після чого на кістку перенесено шкірний трансплантант. Процес адаптації шкірних імплантів проходив без ускладнень (рис. 4, 5).

Пацієнта в задовільному стані на 25 добу виписали для подальшого амбулаторного лікування під наглядом хірурга, гастроентеролога та ендокринолога за місцем проживання. Надано рекомендації. Хворий раз на тиждень приходив для контролю перебігу загоєння трансплантанту. Останній огляд на 35 добу засвідчив повне загоєння трансплантанту (рис. 6).

Висновки. 1. Позакишкові ускладнення неспецифічого виразкового коліту в хірургічній практиці зустрічається в 0,1-0,3 \% випадках. Об'єктивним методом діагностики на даному етапі і надалі залишається колоноскопія.

2. Асоціація захворювання з цукровим діабетом 2 типу значно погіршує перебіг та реабілітацію таких хворих.

3. У випадку коморбідних захворювань лікування вимагає комплексного комбінованого підходу на всі ланки патогенезу поєднаних захворювань.

4. Препарат “Діоксизоль” фірми Дарниця вітчизняного виробництва зарекомендував себе як надійний засіб місцевої терапії у будь-яку фазу ранового процесу. 


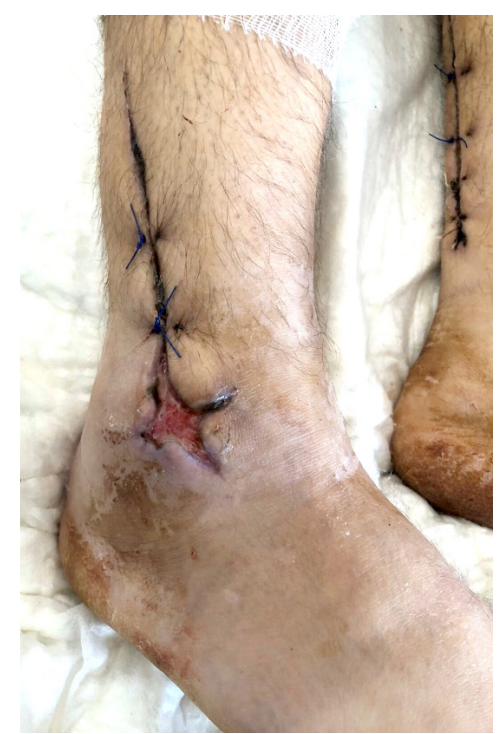

Рис. 1. Накладання вторинних швів на рани обох гомілок.

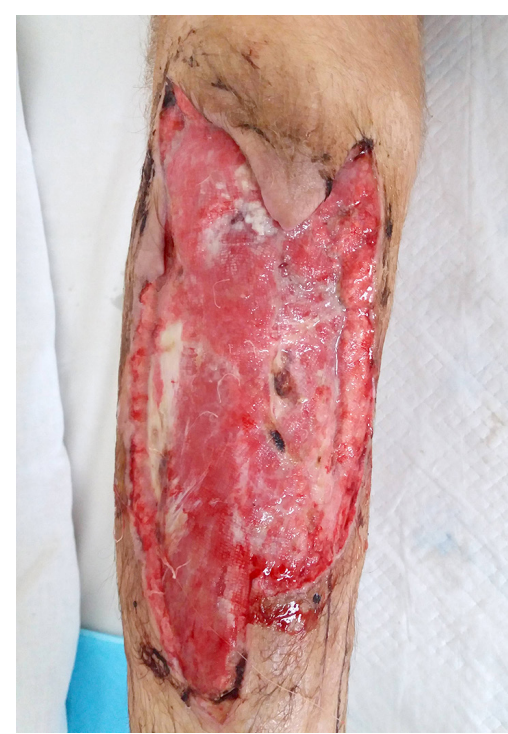

Рис. 2. Вигляд рани на 15 добу після хірургічної обробки.

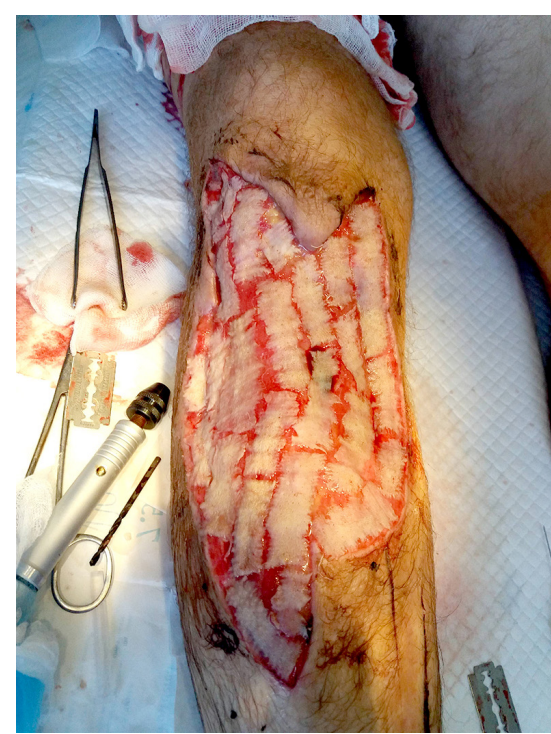

Рис. 3. Вигляд рани після автодермопластики та остеоперфорації.

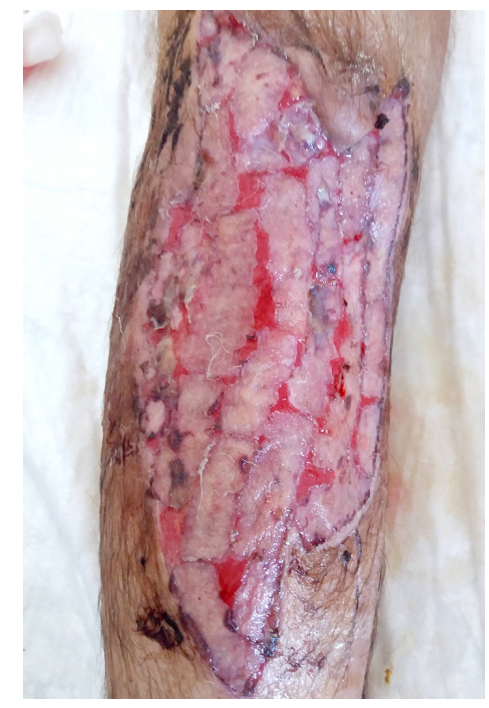

Рис. 4. 7 доба після автодермопластики.

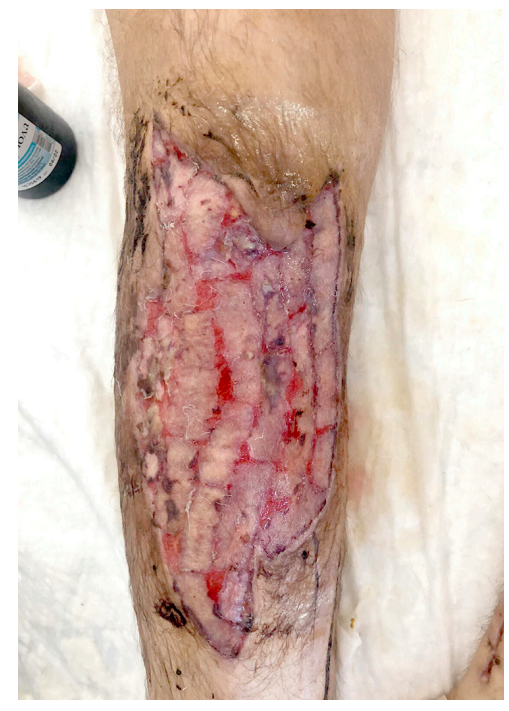

Рис. 5. 14 доба після автодермопластики.

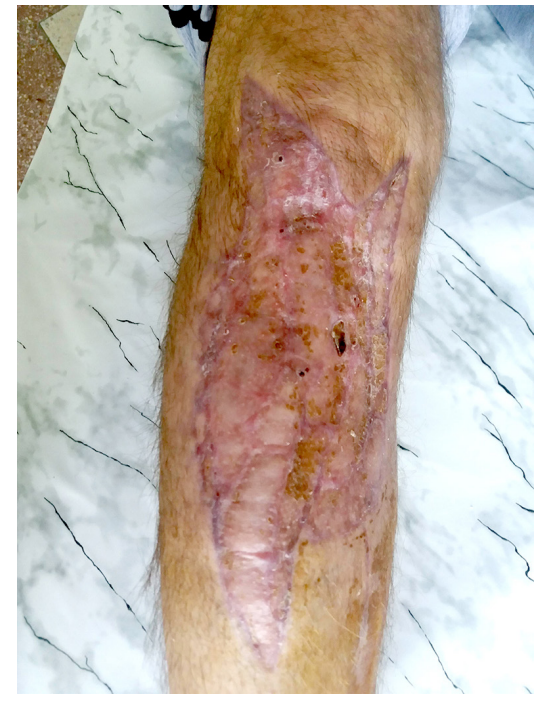

Рис. 6. 35 доба після автодермопластики.
5. Виконання остеоперфорації на оголених частинах кісток дає можливість проводити автодермопластику на поверхню кістки з незначним дефектом без явних грагуляцій.

\section{СПИСОК ЛІТЕРАТУРИ}

1. Ивашкин В. Т. Клинические рекомендации Российской гастроэнтерологической ассоциации и ассоциации колопроктологов России по диагностике и лечению язвенного колита / В. Т. Ивашкин, А. А. Шептулин, О. С. Шифрин [и др.] // Ко-
6. Активна місцева терапія рани антисептичними середниками дає можливість швидко досягти чистоти ранової поверхні та можливості її закриття власною шкірою чи будь-якими шкірними еквівалентами.

лопроктология. - 2017. - № 1 (59). - С. 6-30.

2. Діагностика та хірургічне лікування нейропатичної форми синдрому діабетичної ступні. Актуальні питання екології та охорони здоров’я: зб. праць, т. 6 / I. I. Чонка, А. Д. Бе- 
денюк, В. Б. Доброродній [та ін.]. - Тернопіль : ТДМУ, 2011. - С. 252-267.

3. Уніфікований клінічний протокол медичної допомоги (УКПМД) при запальних захворюваннях кишечника (хвороба Крона, виразковий коліт) : наказ Міністерства охорони здоров’я України від 11.02.2016 № 90.

4. Пластическая хирургия хронических и нейротрофических язв / Г. Д. Никитин, И. П. Карташев, А. В. Рак [и др.]. СПб. : Русская графика, 2001. - 191 с.

5. Футуйма Ю. М. Особливості хірургічної обробки стопи у хворих на цукровий діабет, ускладнений синдромом стопи діабетика / Ю. М. Футуйма, I. I. Чонка, А. В. Павлишин // Z 40 Zbior artikulow naukowych. Konferencji Miedzynarodowej NaukowoPractycznej “Nauka wczoraj, dzis, jutro.” (28.02.2016). - Warszawa : Wydawca: Sp. z o.o. "Diamond trading tour", 2016. - 64 str.

6. Пат. на корисну модель Спосіб ампутації фаланги пальця у хворих на синдром стопи діабетика / Футуйма Ю. М., Чонка I. I., Павлишин А. В. № 109065: Бюл. № 15. - 2016.

7. European evidenced-based Consensus on reproduction in in- flammatory bowel disease / C. J. van der Woude, S. Kolacek, I. Dotan [et al.] // J. Crohns Colitis. - 2010. - Vol. 4. - P. 493-510. 8. European Crohn's and Colitis Organisation. European evidence-based consensus for endoscopy in inflammatory bowel disease / V. Annese, M. Daperno, M. D. Rutter [et al.] // J. Crohns Colitis. - 2013. - Vol. 7. - P. 982-1018.

9. ECCO-ESGAR Guideline for Diagnostic Assessment in IBD Part 2: IBD scores and general principles and technical aspects. Clinical and endoscopic scoring systems in inflammatory bowel disease / A. Sturm, C. Maaser, E. Calabrese [et al.] / Statement 4.1. ECCO-ESGAR Diagnostics GL, 2018.

10. Fecal calprotectin measured by patients at home using smartphones-a new clinical tool in monitoring patients with inflammatory bowel disease / K. K. Vinding, H. Elsberg, T. Thorkilgaard [et al.] // Inflamm Bowel Dis. - 2016. - Vol. 22. - P. 336-344. 11. Prevalence of inflammatory bowel disease among adults aged $\geq 18$ years - United States, 2015 / J. M. Dahlhamer, E. P. Zammitti, B. W. Ward [et al.] // MMWR Morb. Mortal. Wkly. Rep. 2016. - Vol. 65 (42). - P. 1166-1169.

\section{REFERENCES}

1. Ivashkin, V.T., Shelygin, Yu.A., Khalif, I.L., Belousova, Ye.A., Shifrin, O.S., Abdulganiyeva, D.I., ..., \& Yakovlev, A.A. (2017). Klinicheskiye rekomendatsii Rossiyskoy gastroenterologicheskoy assotsiatsii i assotsiatsii koloproktologov Rossii po diagnostike i lecheniyu yazvennogo kolita [Clinical guidelines of the Russian Gastroenterological Association and the Association of Coloproctologists of Russia for the diagnosis and treatment of ulcerative colitis]. Koloproktologiya - Coloproctology, 1 (59), 6-30 [in Russian].

2. Chonka, I.I., Bedeniuk, A.D., \& Dobrorodnii, V.B. (2011). Diahnostyka ta khirurhichne likuvannia neiropatychnoi formy syndromu diabetychnoi stupni. Aktualni pytannia ekolohii ta okhorony zdorovia: zb. prats [Diagnosis and surgical treatment of the neuropathic form of diabetic foot syndrome. Current issues of ecology and health care: Coll. of works]. Ternopil: TDMU [in Ukrainian].

3. Nakaz Ministerstva okhorony zdorovia Ukrainy vid 11.02.2016 № 90: Unifikovanyi klinichnyi protokol medychnoi dopomohy (UKPMD) pry zapalnykh zakhvoriuvanniakh kyshechnyka (khvoroba Krona, vyrazkovyi kolit) [Order of the Ministry of Health of Ukraine of February 11, 2016 No. 90: Unified clinical protocol of medical care (UKPMD) for inflammatory bowel disease (Crohn's disease, ulcerative colitis)]. [in Ukrainian].

4. Nikitin, G.D., Kartashev, I.P., \& Cancer, A.V. (2001). Plasticheskaya khirurgiya khronicheskikh i neyrotroficheskikh yazv [Plastic surgery of chronic and neurotrophic ulcers]. Saint Petersburg: Russian graphics [in Russian].

5. Futuima, Yu.M., Chonka, I.I., \& Pavlyshyn, A.V. (2016). Osoblyvosti khirurhichnoi obrobky stopy u khvorykh na tsukrovyi diabet, uskladnenyi syndromom stopy diabetyka [Features of surgical treatment of the foot in patients with diabetes melli- tus complicated by diabetic foot syndrome]. Z 40 Zbior artikulow naukowych. Konferencji Miedzynarodowej Naukowo-Practycznej "Nauka wczoraj, dzis, jutro.” (28.02.2016) - Warszawa: Wydawca: Sp. z o.o. "Diamond trading tour"' [in Ukrainian]. 6. Futuima, Yu.M., Chonka, I.I., \& Pavlyshyn, A.V. (2016). Sposib amputatsii falanhy paltsia u khvorykh na syndrom stopy diabetyka. Pat. na korysnu model [The method of amputation of the phalanx of the finger in patients with diabetic foot syndrome Patent on the Utility Model No. 109065. Bull. No. 15]. [in Ukrainian]. 7. van der Woude C.J., Kolacek S., Dotan I., Oresland T., Vermeire S., Munkholm P., ..., \& Dignass, A. (2010). European evidenced-based Consensus on reproduction in inflammatory bowel disease. J. Crohns Colitis., 4, 493-510.

8. Annese, V., Daperno, M., Rutter, M.D., Amiot, A., Bossuyt, P., East, J., ..., \& Eliakim, R. (2013). European Crohn's and Colitis Organisation. European evidence-based consensus for endoscopy in inflammatory bowel disease. J. Crohns Colitis, 7, 982-1018. 9. Sturm, A., Maaser, C., Calabrese, E., Annese, V., Fiorino, G., Kucharzik, T., ..., Stoker, J. (2018). Clinical and endoscopic scoring systems in inflammatory bowel disease. Statement 4.1. ECCO-ESGAR Diagnostics GL.

10. Vinding, K.K., Elsberg, H., Thorkilgaard, T., Belard, E., Pedersen, N., Elkjaer, M., ..., \& Munkholm, P. (2016). Fecal calprotectin measured by patients at home using smartphones-a new clinical tool in monitoring patients with inflammatory bowel disease. Inflamm Bowel Dis., 22, 336-344.

11. Dahlhamer, J.M., Zammitti, E.P., Ward, B.W., Wheaton, A.G., \& Croft, J.B. Prevalence of inflammatory bowel disease among adults aged $\geq 18$ years - United States, 2015. (2016). MMWR Morb. Mortal. Wkly. Rep., 65 (42), 1166-1169. 
YU. M. FUTUIMA, A. D. BEDENIUK, S. O. HRABCHAK, A. E. BURAK

I. Horbachevsky Ternopil National Medical University

CLINICAL CASE OF COMPLEXITY OF DIAGNOSIS AND SURGICAL TREATMENT OF EXTRAINTESTINAL COMPLICATIONS IN NONSPECIFIC ULCERATIVE COLITIS ASSOCIATED WITH TYPE II DIABETES

The article presents a case of complexity in the diagnosis and treatment of extraintestinal complications of nonspecific ulcerative colitis and concomitant type II diabetes mellitus in the form of necrotic changes in the tissues of the upper and lower extremities.

Key words: nonspecific ulcerative colitis; type II diabetes, phlegmon; diagnostics; treatment.

Ю. М. ФУТУЙМА, А. Д. БЕДЕНЮК, С. О. ГРАБЧАК, А. Е. БУРАК

Тернопольский национальный медицинский университет имени И. Я. Горбачевского МОЗ Украинь

\section{КЛИНИЧЕСКИЙ С.УУАЙ С.ЛОЖНОСТИ ДИАГНОСТИКИ И ХИРУРГИЧЕСКОГО ЛЕЧЕНИЯ ВНЕКИНЕЧНЫХ ОС.ОЖНЕНИЙ ПРИ НЕСПЕЦИФИЧЕСКОМ ЯЗВЕННОМ КОЛИТЕ, АССОЦИИРОВАННОМ С САХАРНЫМ ДИАБЕТОМ ТИПА 2}

В статье приведен случай сложности диагностики и лечения внекишечного осложнения неспецифического язвенного колита и сопутствующего сахарного диабета 2 типа в виде некротических изменений тканей верхних и нижних конечностей.

Ключевые слова: неспецифический язвенный колит; сахарный диабет 2 типа; флегмона; диагностика; лечение. 